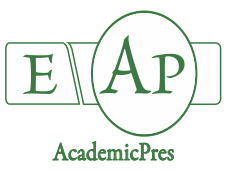

Gaweda M and Jedrszczyk E (2020)

Notulae Botanicae Horti Agrobotanici Cluj-Napoca 48(1):354-365

DOI: $10.15835 /$ nbha48111774

Research Article

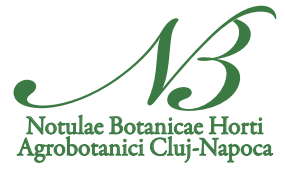

\title{
The effect of cultivar and harvesting stage on the chemical composition of processing tomato fruit
}

\author{
Maria GAWĘDA, Elżbieta JĘDRSZCZYK* \\ University of Agriculture, Faculty of Biotechnology and Horticulture, Department of Horticulture, al. 29 Listopada 54, 31-425 Kraków, \\ Poland; marysia.gaweda@interia.pl; elzbieta.jedrszczyk@urk.edu.pl( ${ }^{*}$ correspondingauthor)
}

\begin{abstract}
Field-grown processing tomatoes are harvested in the red stage, however a significant part of fruits remaining on the crop are at the turning stage and in the mature-green stage. This is a part of the crop that can still be used after post-harvest ripening. The aim of the study was to compare the quality of the three determinate tomato cultivars harvested in the field during the red stage with that of red tomatoes obtained after ripening on shelf (harvested in the turning and mature-green stages). Red fruits were analysed immediately after harvest. The remaining fruits were stored and analysed after they had reached the red stage. Experiment showed that unripe tomatoes harvested in mature green phase during shelf ripening can achieve a good fruit quality, comparable to those harvested red. There was found no impact of the degree of ripeness at harvest on the content of dry matter. The relationship between content of extract, soluble sugars and organic acids and the degree of ripeness at harvest depended on the vegetation period. In 2009 fruits harvested green or pink reached higher content of extract, soluble sugars and organic acids than fruits harvested red. In 2010 it was quite contrary; all parameters were worst in fruits collected green or pink. In 2011 there were no differences in extract, whereas level of sugars and organic acids were higher in fruits collected unripe, stored and analysed after they had reached the red stage. Regardless of the year of research, vitamin C level was always the highest in the fruits collected red.
\end{abstract}

Keywords: acidity; extract; L-ascorbic acid; ripeness stage; sugars

\section{Introduction}

Field-grown processing tomatoes are harvested in the red stage and the raw material is processed quickly. As shown in our previous research (Jędrszczyk et al., 2017), even after application of ethephon 8-14\% of the fruits remaining on the plant are at the turning stage and $16-20 \%$ in the mature-green stage. This is a significant part of the crop that can still be used after post-harvest ripening. However, there are still doubts as to whether the quality of tomatoes harvested in the mature-green stage is comparable to that of tomatoes picked red from the plant. Weingerl and Unuk (2015), for example, report that tomatoes harvested at the commercial maturity stage have higher nutritional value and quality than those harvested in earlier stages of maturation and ripening in storage. On the other hand, the quality of red tomatoes deteriorates sharply after harvest, so they cannot be 
stored for long. The stage of maturity at harvest is also linked to varied susceptibility to mechanical damage (Ferreira et al., 2005).

The content of soluble sugars and organic acids is significantly correlated with flavour attributes (GajcWolska et al., 2000), and thus high content of these two components determines the palatability of the tomatoes. The conflict between early harvest of tomatoes and the reduction in sugars has yet to be resolved (Beckles, 2012). Import of sugars in fruit ripening on the plant increases in the late stages of maturation, whereas in fruit harvested earlier, starch degradation is a source of sugars. As a result, fruits ripening on the plant have more glucose and fructose than those harvested earlier and ripening on the shelf (Karapanos et al., 2015). There are also doubts as to whether tomatoes ripening after harvest have similar antioxidant activity to that of tomatoes ripening on the plant (Ozgen et al., 2012). High-lycopene tomatoes have higher antioxidant activity than traditional tomatoes due to their higher content of carotenoids, especially lycopene (Ilahy et al., 2011; Garcia-Valverde et al., 2013; Tigist et al., 2013). The cultivar factor undoubtedly has a strong influence (Parker and Maalekuu, 2013), although Akbydak (2010) argues that the stage of ripeness may be more important for tomato quality than the cultivar. He reports that processing tomatoes harvested at $85-95 \%$ maturity will produce thicker pastes with higher content of acids and extract.

The aim of the study was to compare the quality of the three cultivars of processing tomato harvested in the field during the red stage with that of red tomatoes obtained after ripening of tomatoes harvested in the turning and mature-green stages, and to determine whether the additional red tomatoes are comparable in quality to those fully ripened in the field. In addition, we analysed the changes over time in selected components from the green stage to the red stage during post-harvest ripening.

\section{Materials and Methods}

\section{Experimental procedures}

The experiment was conducted in an open field at the Experimental Station of the Department of Vegetable and Medicinal Plants in Mydlniki, near Krakow, Poland, in the years 2009-2011. Three cultivars of determinate tomato (Lycopersicon esculentum Mill.) were included in the study: two of Polish breeding, 'Rumba' (Reguły) and 'Mieszko F' (PlantiCo), and one Dutch cultivar, 'Polset F' (Bejo Zaden). They are early cultivars, that go into full fruiting after 70-75 days from planting. Six-week seedlings were planted at $80 \times 60$ $\mathrm{cm}$ spacing at different times each year, depending on weather conditions - 21.05.2009, 29.05.2010, and 16.05.2011. May of 2010 was extremely wet (302 mm of precipitation), which delayed planting. The basic soil fertilization was adjusted to the results of soil analysis, with available forms of mineral constituents added to levels of $\left(\mathrm{mg} \mathrm{dm}^{-3}\right) 120 \mathrm{~N} ; 80 \mathrm{P} ; 250 \mathrm{~K} ; 80 \mathrm{Mg}$. Plots were weeded mechanically as needed. During the growing seasons chemical disease protection was carried out in accordance with the Plant Protection Programme. Irrigation was carried out only in 2009 to supplement precipitation as needed. Sprinkle irrigation provided 12 $\mathrm{mm}$ of water in June and July and $22 \mathrm{~mm}$ in August.

The experiment was set up as a split-block design with four replications. Each plot had an area of 57.6 $\mathrm{m}^{2}$.

\section{Meteorological background}

Weather conditions, i.e. air temperature, precipitation totals and number of days with precipitation were monitored on the experimental plots (Table 1). Air temperature was recorded with HOBO Data Logger sensors (produced by Onset Company Corporation, USA) at the standard level of $2 \mathrm{~m}$, and precipitation was measured with a Hellmann rain gauge at the standard level of $1 \mathrm{~m}$.

Years of the study were highly varied in terms of temperature and precipitation. The conditions in 2009 were most favorable according temperatures and sum and the frequency of precipitation. In 2010 and 2011 the 
356

precipitation totals registered on the experimental plots substantially exceeded the average for the region. In 2010, due to heavy and frequent rainfall in May (302 $\mathrm{mm}$ of precipitation), the plants could not be planted on schedule. Moreover, the level of rainfall in August of that year was nearly twice the average, which impeded correct and timely plant protection procedures.

Table 1. Mean monthly air temperature, total precipitation and number of days with precipitation during the growing period

\begin{tabular}{|c|c|c|c|c|c|c|}
\hline Meteorological elements & Years & May & June & July & August & September \\
\hline \multirow{3}{*}{ Mean temperature $\left({ }^{\circ} \mathrm{C}\right)$} & 2009 & 13.5 & 16.0 & 19.9 & 18.7 & 15.1 \\
\cline { 2 - 7 } & 2010 & 12.8 & 17.5 & 20.7 & 18.4 & 12.1 \\
\cline { 2 - 7 } & 2011 & 12.7 & 17.6 & 20.9 & 18.8 & 12.4 \\
\hline \multirow{3}{*}{\begin{tabular}{c} 
Total precipitation $(\mathrm{mm})$ \\
\cline { 2 - 7 }
\end{tabular}} & 2009 & 97.8 & 140.2 & 82.6 & 53.1 & 35.0 \\
\cline { 2 - 7 } & 2010 & 299.0 & 135.1 & 105.2 & 127.5 & 116.3 \\
\cline { 2 - 7 } $\begin{array}{c}\text { Number of days with } \\
\text { precipitation }\end{array}$ & 2011 & 223.0 & 122.0 & 110.4 & 138.2 & 92.4 \\
\cline { 2 - 7 } & 2009 & 17 & 21 & 15 & 10 & 11 \\
\cline { 2 - 7 } & 2011 & 11 & 16 & 23 & 9 & 6 \\
\hline
\end{tabular}

\section{Harvest procedures}

Fruits were harvested on 7.09.2009, 14.09.2010 and 30.08.2011. All fruits were harvested from the plots, including those that were not yet ripe. Non-marketable fruits, i.e. those that were diseased, poorly developed, or very small, were not used for further observations. Properly shaped and well-developed fruits were divided into three groups, according to the maturity stage: a red group $(80-90 \%$ of the fruit surface is red in colour), a turning group (including pink and turning fruits, where $30-60 \%$ of the fruit surface shows pink or light red colour), and a mature green group (including fully grown but green or breaker fruits, where 10-30\% of the fruit surface is pale yellow).

\section{Postharvest proceedings}

Twenty properly shaped and well-developed fruits were collected for analysis from each maturity stage. Red fruits were analysed immediately after harvest. The remaining fruits were stored at $21{ }^{\circ} \mathrm{C}$ and relatively humidity of $85 \%$, and the analysis was performed after they had reached the red stage.

In the next study changes in the chemical composition of the fruit during storage were examined. Every three days twenty tomatoes from each cultivar were chosen for analysis. The procedure was continued until the fruits of each cultivar were red. This was 14 days ( 5 analyses) in the case of 'Rumba' and 'Polset F' $F_{1}$ and 17 days (6 analyses) for 'Mieszko $F_{1}$ '.

\section{Analysis of chemical composition}

The content of the chemical components of the tomato fruits was tested in three replications. The following parameters were determined:

a) dry matter (\% FW) by the oven-dry method (Pijanowski et al., 2004)

b) total acidity (\% FW) by the titration method using sodium hydroxide (Pijanowski et al., 2004)

c) L-ascorbic acid ( $\mathrm{mg} \%)$ according to Tillmans by titration of extracts with indophenol solution (PN$71 / \mathrm{A} / 75101)$

d) extract $\left({ }^{\circ}\right.$ Brix $)$ with a WYA Abbe refractometer in juice squeezed from the fruits (PN-90/A$75101 / 02)$

e) soluble sugars (\% FW) by the anthrone colorimetric method (Yemm and Wills, 1954) following extraction with ethyl alcohol; their extinction was determined with a UV-VIS Helios $\beta$ spectrophotometer. 


\section{Statistical procedures}

The results were statistically analysed using analysis of variance for double classification by Tukey's HSD test for unequal N, with $\mathrm{p}<0.05$, in Statistica Software. This test was chosen due to the unequal numbers of analyses for different cultivars during ripening.

\section{Results}

In 2009, tomatoes of the 'Mieszko $F_{1}$ ' cultivar harvested at the mature-green stage had $8 \%$ more dry matter than tomatoes harvested when they were red (Table 2). In the case of the 'Rumba' cultivar, red fruits had 10\% more dry matter than fruits harvested in other stages. The dry matter of the 'Polset $\mathrm{F}_{1}$ ' tomatoes did not vary depending on the harvesting time. The 'Mieszko $F_{1}$ ' tomatoes harvested at the green and turning stages contained $18 \%$ more extract than the tomatoes harvested in the red stage. The 'Rumba' and 'Polset $F_{1}$ ' fruits had the highest content of this component when they were harvested at the turning stage: by $6 \%$ and $21 \%$ more than those picked in the red stage. The content of soluble sugars in the 'Mieszko $F_{1}$ ' and 'Rumba' tomatoes did not depend on the time of harvest. 'Polset $\mathrm{F}_{1}$ ' tomatoes harvested during the green and turning stages had 26\% more sugars than those harvested in the red stage. The 'Mieszko $F_{1}$ ' tomatoes harvested in the green stage had the highest content of organic acids, by $19 \%$ more than in the fruits harvested in the red stage. The reverse was true for 'Rumba', with $9 \%$ more acids noted in the fruits harvested in the turning and red stages. 'Polset $F_{1}$ ' tomatoes harvested in the green and turning stages had 31\% higher acidity than tomatoes harvested in the red stage. The 'Mieszko $F_{1}$ ' and 'Polset $F_{1}$ ' tomatoes harvested in the turning and red stages contained more ascorbic acid (48\% and 23\% more than those harvested in the green stage). 'Rumba' tomatoes did not vary in ascorbic acid content depending on when they were harvested.

Table 2. Content of selected components in ripe tomatoes of three cultivars harvested at different stages of ripeness in 2009

\begin{tabular}{|c|c|c|c|c|c|c|}
\hline $\begin{array}{c}\text { Stage of } \\
\text { ripeness at } \\
\text { harvest }\end{array}$ & Cultivar & $\begin{array}{l}\text { Dry matter } \\
(\% \mathrm{FW})\end{array}$ & $\begin{array}{l}\text { Extract } \\
\text { ( }{ }^{\circ} \text { Brix) }\end{array}$ & $\begin{array}{l}\text { Soluble sugars } \\
\quad(\% \mathrm{FW})\end{array}$ & $\begin{array}{c}\text { Organic acids } \\
\qquad(\% \mathrm{FW})\end{array}$ & $\begin{array}{c}\text { Ascorbic acid } \\
(\mathrm{mg} \%)\end{array}$ \\
\hline Green & \multirow{3}{*}{ 'Mieszko $\mathrm{F}_{1}$ ' } & $5.96 b^{*}$ & $5.02 \mathrm{bc}$ & $2.25 \mathrm{bc}$ & $0.38 \mathrm{~d}$ & $10.3 \mathrm{a}$ \\
\hline Turning & & $5.70 \mathrm{ab}$ & $5.02 \mathrm{bc}$ & $2.14 \mathrm{abc}$ & $0.32 \mathrm{~b}$ & $15.2 \mathrm{~b}$ \\
\hline Red & & $5.52 \mathrm{a}$ & $4.30 \mathrm{a}$ & $2.25 \mathrm{bc}$ & $0.29 a$ & $15.2 \mathrm{~b}$ \\
\hline Green & \multirow{3}{*}{ 'Rumba' } & $5.38 \mathrm{a}$ & $4.82 \mathrm{~b}$ & $2.17 \mathrm{bc}$ & $0.32 \mathrm{~b}$ & $19.6 \mathrm{c}$ \\
\hline Turning & & $5.42 \mathrm{a}$ & $5.22 \mathrm{~cd}$ & $2.06 \mathrm{ab}$ & $0.35 \mathrm{c}$ & $19.2 \mathrm{c}$ \\
\hline Red & & $5.92 \mathrm{~b}$ & $4.92 \mathrm{~b}$ & $2.23 \mathrm{bc}$ & $0.35 \mathrm{c}$ & $20.5 c$ \\
\hline Green & \multirow{3}{*}{ 'Polset $F_{1}$ ' } & $5.70 \mathrm{ab}$ & $4.88 \mathrm{~b}$ & $2.36 \mathrm{c}$ & $0.42 \mathrm{e}$ & $16.4 \mathrm{~b}$ \\
\hline Turning & & $5.63 \mathrm{ab}$ & $5.38 \mathrm{~d}$ & $2.40 \mathrm{c}$ & $0.42 \mathrm{e}$ & $19.7 \mathrm{c}$ \\
\hline Red & & $5.54 \mathrm{a}$ & $4.42 \mathrm{a}$ & $1.89 \mathrm{a}$ & $0.32 \mathrm{~b}$ & $20.5 c$ \\
\hline Green & \multirow{3}{*}{ Mean } & $5.68 \mathrm{~A}$ & $4.90 \mathrm{~B}$ & $2.26 \mathrm{~B}$ & $0.37 \mathrm{C}$ & $15.4 \mathrm{~A}$ \\
\hline Turning & & $5.58 \mathrm{~A}$ & $5.20 \mathrm{C}$ & $2.20 \mathrm{~B}$ & $0.36 \mathrm{~B}$ & $18.0 \mathrm{~B}$ \\
\hline Red & & $5.66 \mathrm{~A}$ & $4.55 \mathrm{~A}$ & $2.05 \mathrm{~A}$ & $0.32 \mathrm{~A}$ & $18.7 \mathrm{C}$ \\
\hline
\end{tabular}

Analysis of the averages for the three cultivars in 2009 of the effect of the stage of maturation at harvest on the content of selected components in ripe tomatoes showed that the dry matter content in fruits varied from 5.58 to $5.68 \%$ of fresh weight and the impact of harvesting phase was not significant. The level of extract varied from 4.55 to $4.90^{\circ}$ Brix. Tomatoes harvested in the turning stage had the most extract, $14.5 \%$ more than those harvested in the red stage, which had the least extract. Tomatoes harvested in the green and turning stages had $2.20-2.26 \%$ FW soluble sugars and it was $8.8 \%$ more than tomatoes harvested in the red stage. The content 
358

of organic acids after ripening the tomatoes harvested when they were green was $0.37 \% \mathrm{FW}$. It was $15.6 \%$ higher than in tomatoes harvested in the red-ripe stage. The least ascorbic acid was accumulated in the tomatoes harvested in the green stage $(15.4 \mathrm{mg} \%)$, in comparison with the fruit harvested in the red stage $(18.7 \mathrm{mg} \%)$.

In 2010 no differences were noted in the dry matter of the tomatoes of the cultivars depending on the stage of ripening at harvest (Table 3). Extract in the 'Mieszko $F_{1}$ ' tomatoes harvested in the red stage was somewhat higher (by 6\%) than in those harvested at the turning and green stages. No significant differences in extract were noted in the 'Rumba' tomatoes. The 'Polset $F_{1}$ ' tomatoes harvested in the turning stage had the most extract, $6 \%$ more than those harvested in the other stages. The 'Mieszko $F_{1}$ ' and 'Polset $F_{1}$ ' fruit collected in the red stage had the highest content of soluble sugars, which was $36 \%$ and $17 \%$ more than in the case of the tomatoes harvested in the turning and green stages. The reverse was observed for the 'Rumba' tomatoes, which contained more sugars when harvested in the green and turning stages, $49 \%$ more than those harvested in the red stage. The content of organic acids in the 'Mieszko $F_{1}$ ' fruits did not depend on when they were harvested. The 'Rumba' tomatoes had the highest acidity when they were harvested in the red stage $-38 \%$ higher than those harvested in the turning stage, which had the lowest acidity. The 'Polset $F_{1}$ ' fruits harvested at different stages of maturation varied only slightly in their content of acids. The 'Mieszko $F_{1}$ ' and 'Polset $F_{1}$ ' tomatoes harvested in the turning stage had the most ascorbic acid - 37\% and 70\% more than in the fruits of these cultivars harvested in the red ('Mieszko $F_{1}$ ') and green ('Polset $F_{1}$ ') stages. The 'Rumba' fruit harvested in the red stage had the highest content of ascorbic acid, $75 \%$ more than fruits of this cultivar harvested in the green stage.

Table 3. Content of selected components in ripe tomatoes of three cultivars harvested at different stages of ripeness in 2010

\begin{tabular}{|c|c|c|c|c|c|c|}
\hline $\begin{array}{c}\text { Stage of } \\
\text { ripeness at } \\
\text { harvest }\end{array}$ & Cultivar & $\begin{array}{l}\text { Dry matter } \\
(\% \mathrm{FW})\end{array}$ & $\begin{array}{l}\text { Extract } \\
\left.\text { ( }{ }^{\circ} \text { Brix }\right)\end{array}$ & $\begin{array}{c}\text { Soluble } \\
\text { sugars } \\
(\% \text { FW) }\end{array}$ & $\begin{array}{l}\text { Organic acids } \\
\quad(\% \mathrm{FW})\end{array}$ & $\begin{array}{c}\text { Ascorbic acid } \\
(\mathrm{mg} \%)\end{array}$ \\
\hline Green & \multirow{3}{*}{ 'Mieszko F ' } & 4.70 bcd $^{*}$ & $3.94 \mathrm{bc}$ & $1.38 \mathrm{~cd}$ & $0.32 \mathrm{a}$ & $16.2 \mathrm{~d}$ \\
\hline Turning & & $4.80 \mathrm{~cd}$ & $3.94 \mathrm{bc}$ & $1.31 \mathrm{c}$ & $0.34 \mathrm{ab}$ & $19.4 \mathrm{e}$ \\
\hline Red & & $4.99 \mathrm{~d}$ & $4.19 \mathrm{~d}$ & $1.82 \mathrm{f}$ & $0.35 \mathrm{ab}$ & $14.2 \mathrm{bc}$ \\
\hline Green & \multirow{3}{*}{ 'Rumba' } & $4.41 \mathrm{abc}$ & $3.95 \mathrm{bc}$ & $1.45 \mathrm{de}$ & $0.36 \mathrm{~b}$ & $15.8 \mathrm{~cd}$ \\
\hline Turning & & $4.50 \mathrm{abc}$ & $4.08 \mathrm{~cd}$ & $1.48 \mathrm{e}$ & $0.32 \mathrm{a}$ & $24.0 \mathrm{f}$ \\
\hline Red & & $4.30 \mathrm{ab}$ & $3.89 \mathrm{~b}$ & $0.98 \mathrm{~b}$ & $0.44 c$ & $27.6 \mathrm{~g}$ \\
\hline Green & \multirow{3}{*}{ 'Polset $F_{1}$ ' } & $4.12 \mathrm{a}$ & $3.74 \mathrm{a}$ & $0.84 \mathrm{a}$ & $0.55 \mathrm{e}$ & $10.8 \mathrm{a}$ \\
\hline Turning & & $4.34 \mathrm{abc}$ & $4.04 \mathrm{c}$ & $0.84 \mathrm{a}$ & $0.51 \mathrm{~d}$ & $18.4 \mathrm{e}$ \\
\hline Red & & $4.21 \mathrm{a}$ & $3.84 \mathrm{ab}$ & $0.98 \mathrm{~b}$ & $0.52 \mathrm{de}$ & $13.9 \mathrm{~b}$ \\
\hline Green & \multirow{3}{*}{ Mean } & $4.41 \mathrm{~A}$ & $3.88 \mathrm{~A}$ & $1.22 \mathrm{~A}$ & $0.41 \mathrm{~B}$ & $14.2 \mathrm{~A}$ \\
\hline Turning & & $4.54 \mathrm{~A}$ & $4.02 \mathrm{~B}$ & $1.21 \mathrm{~A}$ & $0.39 \mathrm{~A}$ & $20.6 \mathrm{C}$ \\
\hline Red & & $4.50 \mathrm{~A}$ & $3.97 \mathrm{~B}$ & $1.26 \mathrm{~B}$ & $0.44 \mathrm{C}$ & $18.6 \mathrm{~B}$ \\
\hline
\end{tabular}

${ }^{*}$ Values marked with the same letter within the same components and for means do not differ significantly

On average for the cultivars in 2010 the effect of the stage of ripening at harvest on dry matter content was not significant. For the fruit collected in the turning and red stages, $3 \%$ more extract was noted than for the tomatoes harvested at the green stage ( 3.94 Brix). Tomatoes harvested at the red stage had $1.26 \% \mathrm{FW}$ sugars, it was $4 \%$ more than tomatoes harvested in other stages $(1.21-1.22 \% \mathrm{FW})$. The highest acidity $(0.44 \%$ FW) was shown in the case of fruit harvested when it was red, and the lowest $(0.39 \% \mathrm{FW})$ in the fruit harvested at the turning stage (by 12.8\%). The tomatoes harvested in the turning stage had the most ascorbic acid (20.6 $\mathrm{mg} \%), 45 \%$ more than those harvested in the green stage $(14.2 \mathrm{mg} \%)$.

The analyses conducted in 2011 showed that the dry matter of the 'Mieszko F', 'Rumba' and 'Polset $F_{1}$ ' tomatoes did not significantly depend on when they were harvested (Table 4). The highest extract content was noted in the 'Mieszko $F_{1}$ ' tomatoes harvested at the green stage - $11 \%$ higher than in the tomatoes harvested 
in the other stages. The 'Rumba' fruits harvested at different stages of ripeness did not clearly differ in their content of this component. The 'Polset $\mathrm{F}_{1}$ ' tomatoes harvested at the red stage contained the most extract, $16 \%$ more than those picked at the turning stage. The tomatoes of all cultivars harvested at the red stage contained the least soluble sugars, $52 \%$ less than those harvested at the turning stage ('Mieszko $\mathrm{F}_{1}{ }^{\prime}$ ), $44 \%$ less than tomatoes picked at other stages ('Rumba'), and $55 \%$ less than fruit harvested at the green stage ('Polset $\mathrm{F}_{1}{ }^{\prime}$ ). The highest content of organic acids was found in the tomatoes of all cultivars harvested in the green stage; this was $27 \%$ and $15 \%$ more than in the tomatoes harvested in other stages ('Mieszko $F_{1}$ ' and 'Rumba') and $42 \%$ more than in those harvested in the red stage ('Polset $F_{1}{ }^{\prime}$ ). The fruit harvested at the red stage contained the most ascorbic acid. This was true for all cultivars tested: they had $40 \%$ more of this compound than the tomatoes harvested in the green stage ('Mieszko $\mathrm{F}_{1}$ '), and $62 \%$ and $42 \%$ more than the tomatoes collected at the green and turning stages ('Rumba' and 'Polset $F_{1}$ ').

Table 4. Content of selected components in ripe tomatoes of three cultivars harvested at different stages of ripeness in 2011

\begin{tabular}{|c|c|c|c|c|c|c|}
\hline $\begin{array}{c}\text { Stage of } \\
\text { ripeness at } \\
\text { harvest }\end{array}$ & Cultivar & $\begin{array}{l}\text { Dry matter } \\
(\% \mathrm{FW})\end{array}$ & $\begin{array}{l}\text { Extract } \\
\text { (oBrix) }\end{array}$ & $\begin{array}{c}\text { Soluble sugars } \\
\quad(\% \mathrm{FW})\end{array}$ & $\begin{array}{l}\text { Organic acids } \\
\qquad(\% \mathrm{FW})\end{array}$ & $\begin{array}{c}\text { Ascorbic acid } \\
(\mathrm{mg} \%)\end{array}$ \\
\hline Green & \multirow{3}{*}{ 'Mieszko F' } & $5.82{b c^{*}}^{*}$ & $5.35 \mathrm{~cd}$ & $2.39 \mathrm{e}$ & $0.42 \mathrm{c}$ & $17.4 \mathrm{ab}$ \\
\hline Turning & & $5.84 \mathrm{c}$ & $4.85 \mathrm{ab}$ & $2.56 \mathrm{f}$ & $0.32 \mathrm{a}$ & $19.8 \mathrm{~b}$ \\
\hline Red & & $5.86 \mathrm{c}$ & $4.75 \mathrm{ab}$ & $1.24 \mathrm{~b}$ & $0.34 \mathrm{ab}$ & $24.4 \mathrm{c}$ \\
\hline Green & \multirow{3}{*}{ 'Rumba' } & $5.24 \mathrm{ab}$ & $4.45 \mathrm{a}$ & $2.20 \mathrm{~cd}$ & $0.38 \mathrm{bc}$ & $17.0 \mathrm{a}$ \\
\hline Turning & & $5.01 \mathrm{a}$ & $4.88 \mathrm{~b}$ & $2.22 \mathrm{~cd}$ & $0.35 \mathrm{ab}$ & $16.5 \mathrm{a}$ \\
\hline Red & & $5.41 \mathrm{abc}$ & $4.65 \mathrm{ab}$ & $1.25 \mathrm{~b}$ & $0.32 \mathrm{a}$ & $27.2 \mathrm{~d}$ \\
\hline Green & \multirow{3}{*}{ 'Polset $F_{1}$ ' } & $5.80 \mathrm{bc}$ & $5.00 \mathrm{bc}$ & $2.35 \mathrm{de}$ & $0.54 \mathrm{e}$ & $17.1 \mathrm{a}$ \\
\hline Turning & & $5.18 \mathrm{a}$ & $4.70 \mathrm{ab}$ & $2.05 \mathrm{c}$ & $0.48 \mathrm{~d}$ & $16.0 \mathrm{a}$ \\
\hline Red & & $5.46 \mathrm{abc}$ & $5.45 \mathrm{~d}$ & $1.05 \mathrm{a}$ & $0.38 \mathrm{bc}$ & $23.4 \mathrm{c}$ \\
\hline Green & \multirow{3}{*}{ Mean } & $5.62 \mathrm{~B}$ & $4.93 \mathrm{~A}$ & $2.31 \mathrm{~B}$ & $0.45 \mathrm{C}$ & $17.2 \mathrm{~A}$ \\
\hline Turning & & $5.34 \mathrm{~A}$ & $4.80 \mathrm{~A}$ & $2.28 \mathrm{~B}$ & $0.38 \mathrm{~B}$ & $17.4 \mathrm{~A}$ \\
\hline Red & & $5.58 \mathrm{AB}$ & $4.95 \mathrm{~A}$ & $1.18 \mathrm{~A}$ & $0.35 \mathrm{~A}$ & $25.0 \mathrm{~B}$ \\
\hline
\end{tabular}

${ }^{*}$ Values marked with the same letter within the same components and for means do not differ significantly

On average in 2011 dry matter content in fruit varied from 5.34 to $5.62 \% \mathrm{FW}$. The tomatoes harvested in the green stage had the highest dry matter content after ripening: $5 \%$ higher than that of tomatoes harvested at the turning stage. The ripening stage at harvest was not found to affect the content of extract in the tomatoes ready for processing. The content of soluble sugars in the tomatoes harvested at the turning and green stages varied from 2.28 to $2.31 \% \mathrm{FW}$ and was on average $47 \%$ higher than in the fruit collected in the red stage $(1.18 \%$ FW). The content of organic acids in the tomatoes harvested when they were red was $29 \%$ lower than in the tomatoes harvested at the green stage $(0.45 \% \mathrm{FW})$. The tomatoes harvested in the green and turning stage contained the least ascorbic acid (17.2-17.4 mg\%), with those harvested at the red stage having $45 \%$ more of this compound $(25 \mathrm{mg} \%)$.

Figure 1 shows the changes in the content of dry matter during the ripening of harvested green tomatoes until they became sufficiently ripe for processing. In 2009 the tomatoes contained the driest matter at the moment of harvest. It then decreased somewhat (by $9.6 \%$ after 7 days) and then increased again to its original level. Similar changes were observed in 2011 (5.3\% decrease after one week). In 2010 the driest matter was also noted after harvest. Since $7^{\text {th }}$ day on shelf definitely decrease was observed (by $11.1 \%$ in accordance to the beginning level).

In 2009 the lowest content of extract in the tomatoes was noted at harvest (Figure 2), after which it gradually increased, and the red fruit had $11 \%$ more of this component than the green fruit. In the following 
360

year there was no pronounced change in extract throughout the experiment. In 2011 the content of extract in the first few days of ripening decreased by $5 \%$ and then again rose to its initial level.

$(\%)$

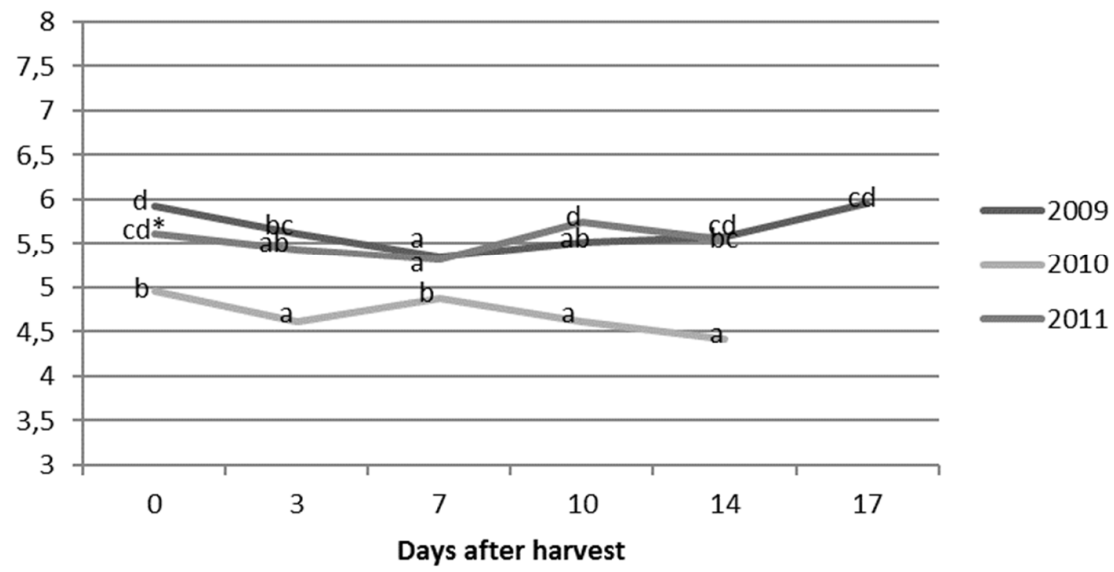

Figure 1. Changes in dry matter (\% FW) content during tomato ripening in the three years of the experiment (means for three cultivars). ${ }^{*}$ Values marked with the same letter within the same year do not differ significantly

('Brix)

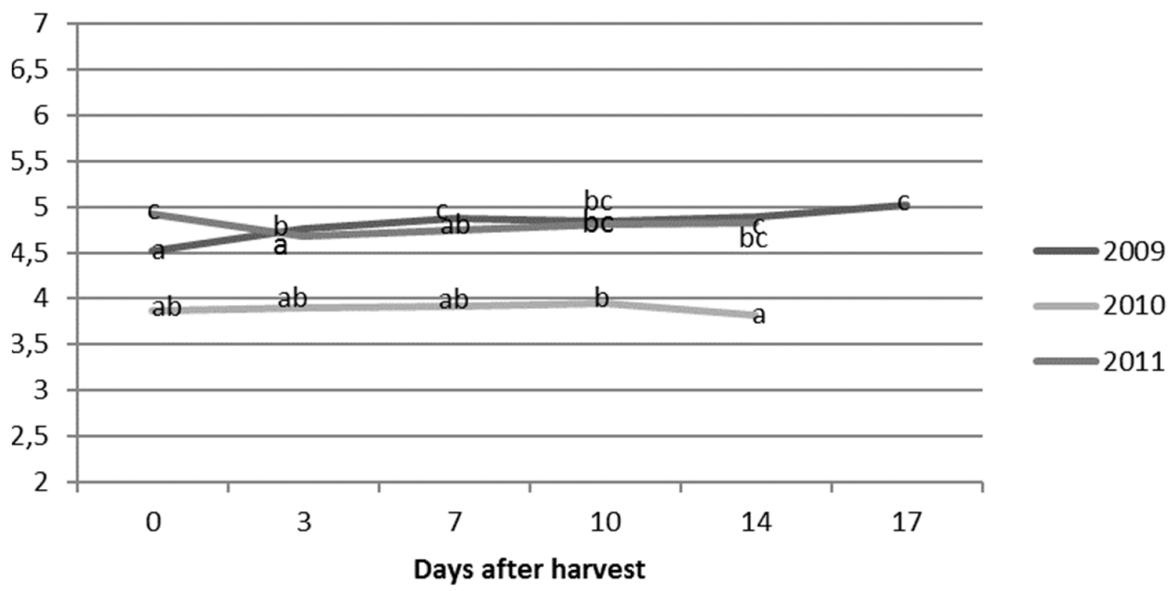

Figure 2. Changes in content of extract $\left({ }^{\circ} \mathrm{Brix}\right)$ during tomato ripening in the three years of the experiment (means for three cultivars). ${ }^{*}$ Values marked with the same letter within the same years do not differ significantly

In the first year of the study the highest content of soluble sugars was noted in the harvested green tomatoes (Figure 3). Between the first and third day of ripening their content decreased by nearly $20 \%$, and then again approached their initial level. The content of sugars in the tomatoes harvested in 2010 decreased throughout the ripening period (ultimately by $32 \%$ ), with significant reductions noted between the $3^{\text {rd }}$ and $7^{\text {th }}$ days and between the $7^{\text {th }}, 10^{\text {th }}$ and 14th days. The sugar content in the fruit harvested in 2011 remained at a fairly stable level; only between the $3^{\text {rd }}$ and $7^{\text {th }}$ day of ripening was a $6 \%$ decrease observed.

Changes in acidity during tomato ripening in 2009 were minor and not statistically significant (Figure 4). In 2010 no differences were noted in the content of organic acids in the green and red tomatoes, but acidity decreased significantly between harvest and the $3^{\text {rd }}$ day of ripening and between the $7^{\text {th }}$ and $10^{\text {th }}$ days of ripening, 
and increased significantly between the $3^{\text {rd }}$ and $7^{\text {th }}$ days and also between the $10^{\text {th }}$ and $14^{\text {th }}$ days. In 2011 the red tomatoes had $15 \%$ lower content of organic acids than the tomatoes at the moment of harvest; a decrease in their content occurred between the $7^{\text {th }}$ and $10^{\text {th }}$ days of ripening.

The highest ascorbic acid content in 2009 was noted in the green tomatoes (Figure 5). Only after 14 days of ripening did it decrease by about 19\%. Similarly, in 2010 the tomatoes after harvest contained the highest content of this compound. During ripening, ascorbic acid content decreased at a uniform rate, ultimately by 25\%. In 2011 the reverse tendency was observed: the least ascorbic acid was observed in the harvested tomatoes. Within the first seven days its content increased by about 33\% and remained at this level until the tomatoes were fully ripe.

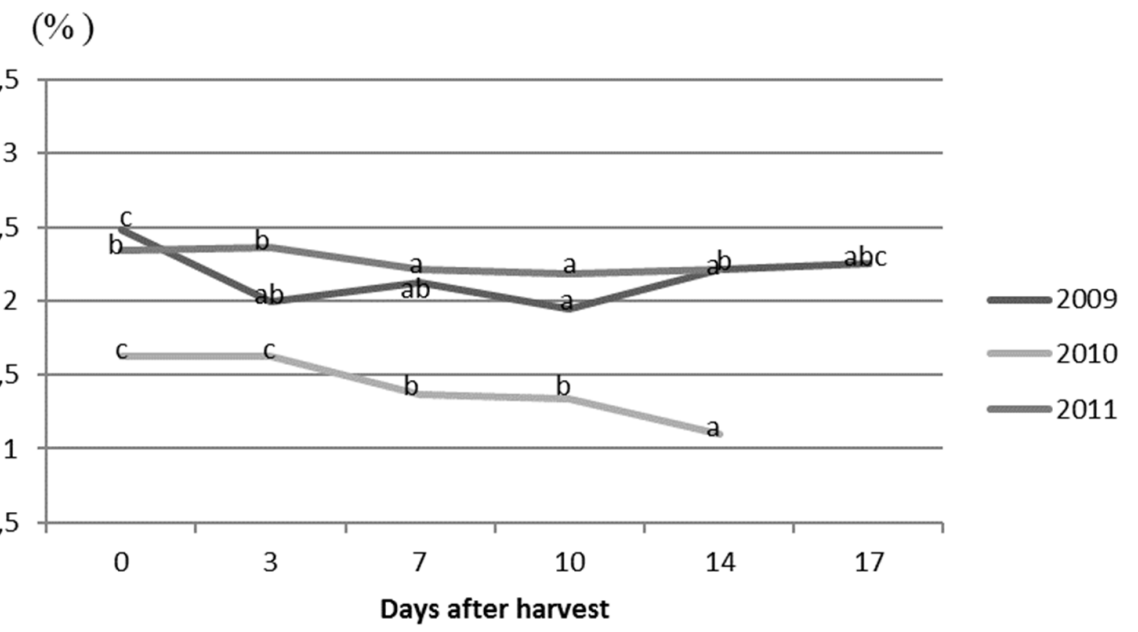

Figure 3. Changes in content of soluble sugars (\% FW) during tomato ripening in the three years of the experiment (means for three cultivars). *Values marked with the same letter within the same years do not differ significantly

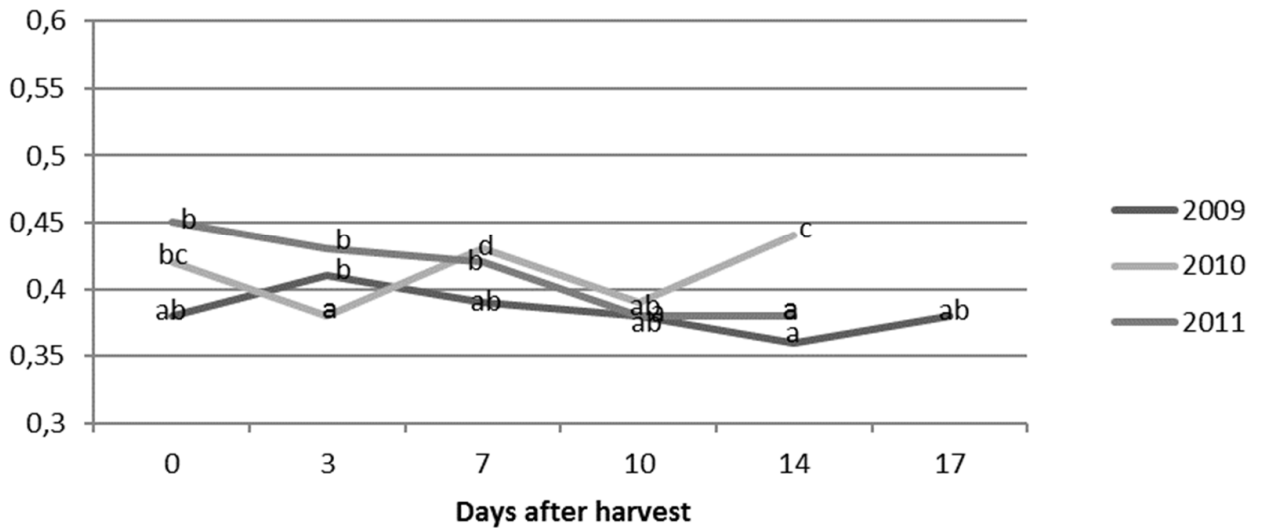

Figure 4. Changes in content of total acidity (\% FW) during tomato ripening in the three years of the experiment (means for three cultivars). *Values marked with the same letter within the same years do not differ significantly 


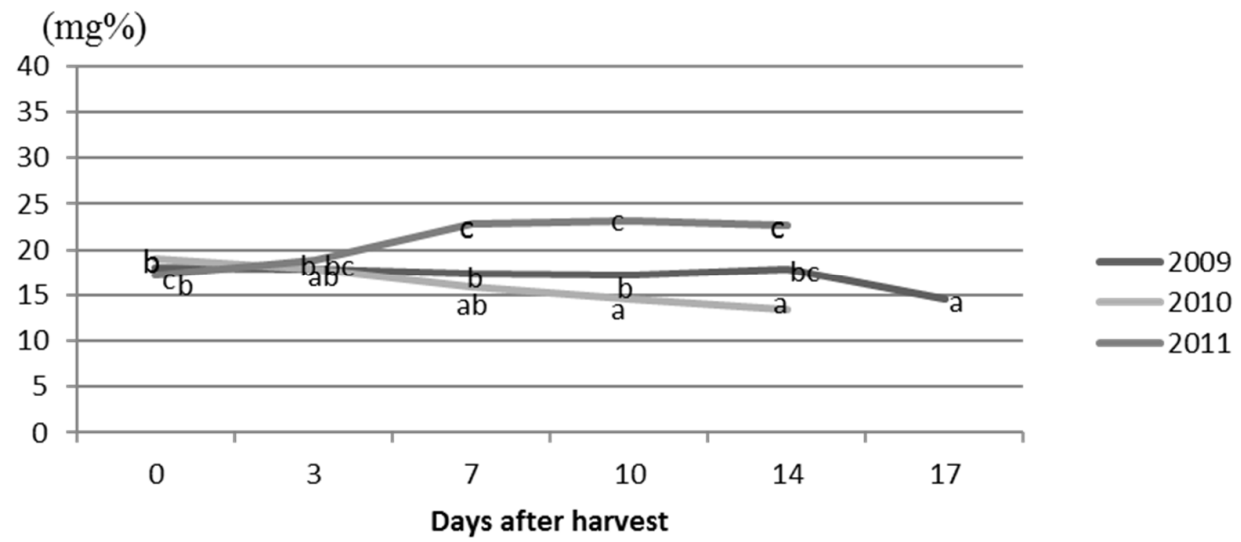

Figure 5. Changes in L-ascorbic acid ( $\mathrm{mg} \%$ ) content during tomato ripening in the three years of the experiment (means for three cultivars). ${ }^{*}$ Values marked with the same letter within the same years do not differ significantly

\section{Discussion}

It has long been disputed whether the quality of tomatoes harvested when they are fully-developed but green and ripened off the plant to the stage of commercial maturity can equal that of tomatoes reach this stage on the plant (Hong and Lee, 1999). According to Saltveit (2005), there is no substantial difference between them, while Moneruzzaman et al. (2008) claim that tomatoes harvested when they are fully ripe contain the most sugars and extract, while tomatoes picked when they are half-ripe contain the most vitamin $\mathrm{C}$ and titratable acids. Our three-year study of tomatoes of the 'Mieszko $\mathrm{F}_{1}$,' 'Rumba' and 'Polset $\mathrm{F}_{1}$ ' cultivars harvested at different stages of ripeness has shown that the degree of ripeness at harvest did not affect the content of dry matter in the processing tomatoes or influenced it to a small degree. In the case of ascorbic acid, the results are also conclusive. The lowest level of this compound was detected in the tomatoes harvested in the green stage and the highest in those picked during the red or turning stage. The correlation between content of extract and the phase of fruit ripeness in individual years of research is not clear. It is probably strongly dependent on the weather conditions over the growing season. The highest content of extract in the crop from 2009 and 2010 was detected in the tomatoes harvested at the turning stage, while in 2011 it was not varied. In a study on the 'Roma VF' and 'Marglobe' cultivars, the most extract was also noted in tomatoes at the turning stage, and the least in fruit harvested during the green stage (Getinet et al., 2008). The content of soluble sugars and organic acids decreased as the fruit ripened in 2009 and 2011, while in 2010 the reverse trend was observed, as the red tomatoes contained the most sugars and organic acids. This is probably related to the course of rainfall in these growing seasons. The year 2011 was marked by very intense and frequent rainfall during fruit ripening (August, September).

During the ripening of green tomatoes, no constant trend was observed in the changes in the components analysed, which were minor. In 2010 we observed a decrease in dry matter, soluble sugars and Lascorbic acid content. This decrease in 2010 year is in contrast to other years of investigation, with more favourable precipitation course, where the ingredients remained at the same level. Perhaps this is related to the condition of the fruit at harvest. Studies by other authors do not provide conclusive answers. According to Arah et al. (2015), turning tomatoes have the highest acidity, which rapidly decreases as the fruit ripens. Takahashi et al. (2014) also report that acidity and sugar content decrease in turning tomatoes as they ripen. On the other hand, Moneruzzaman et al. (2009) state that the titratable acidity and content of soluble sugars in Roma VF tomatoes harvested at various stages of ripeness increased during storage at $28^{\circ} \mathrm{C}$ and $75 \%$ relative humidity, while vitamin C content decreased. Similar observations were made by Hatami et al. (2013). On the 
other hand, Oms-Oliu et al. (2011) claim that the content of L-ascorbic acid increases up to the turning stage and subsequently decreases. Toor and Savage (2006) report that during storage of tomatoes harvested in the turning stage they observed a slight increase in the content of ascorbic acid. Javanmardi and Kubota (2006) reported that extract remained unchanged in turning and red tomatoes of the Clermont cultivar stored at room temperature, while a similar experiment with 'Chali' tomatoes showed an increase in this component (Abiso $e t$ al., 2015).

The results of the experiment indicate that unripe tomatoes harvested in the mature green phase during shelf ripening can achieve good fruit quality. In years with favourable weather conditions there were no decreases in content of dry matter, sugars and L-ascorbic acid in fruits during shelf ripening.

\section{Conclusions}

Experiment showed that unripe tomatoes harvested in mature green phase during shelf ripening can achieve a good fruit quality, comparable to those harvested red. There was found no impact of the degree of ripeness at harvest on the content of dry matter. The relationship between content of extract, soluble sugars and organic acids and the degree of ripeness at harvest depended on the vegetation period. In 2009 fruits harvested green or pink reached higher content of extract, soluble sugars and organic acids than fruits harvested red. In 2010 it was quite contrary; all parameters were worst in fruits collected green or pink. In 2011 there were no differences in extract, whereas level of sugars and organic acids were higher in fruits collected unripe, stored and analysed after they had reached the red stage. Regardless of the year of research, vitamin C level was always the highest in the fruits collected red.

\section{Acknowledgements}

Research carried out under the project: 6ZR7 2008 C/07085, "Development and implementation of technology of tomato products with high lycopene content”. Research task: BZ 662/KWz EO/09-11.

\section{Conflict of Interests}

The authors declare that there are no conflicts of interest related to this article.

\section{References}

Abiso E, Satheesh N, Hailu A (2015). Effect of storage methods and ripening stages on postharvest quality of tomato (Lycopersicon esculentum Mill.) cv. Chali. An. Food Science and Technology 16(1):127-138.

Akbydak B (2010). Effects of harvest time on the quality attributes of processed and non-processed tomato varieties. International Journal of Food Science Technology 45:334-343.

Arah IK, Amaglo H, Kumah EK, Ofori H (2015). Preharvest and postharvest factors affecting the quality and shelf life of harvested tomatoes. A mini review. International Journal of Agronomy. Article ID 478041.

Beckles DM (2012): Factors affecting the postharvest soluble solids and sugar content of tomato (Solanum lycopersicum L.) fruit. Postharvest Biology and Technology 63:129-140.

Ferreira MD, Franco ATO, Kasper RF, Ferraz ACO, Honorio SL, Tavares M (2005). Post-harvest quality of fresh-marked tomatoes as a function of harvest periods. Scientia Agricola (Piracicata, Braz.) 62(5):446-451. 
Gajc-Wolska J, Skapski H, Szymczak JA (2000). Chemical and sensory characteristics of the fruits of eight cultivars of field grown tomato. Acta Physiologiae Plantarum 22(3):369-373.

Garcia-Valverde V, Navarro-Gonzalez J, Garcia-Alonso J, Periago MJ (2013). Antioxidant bioactive compounds in selected industrial processing and fresh consumption tomato cultivars. Food Bioprocess Technology 6:391-402.

Getinet H, Seyoum T, Woldetsadik K (2008). The effect of cultivar, maturity stage and storage environment on quality of tomatoes. Journal of Food Engineering 87:467-478.

Hatami M, Kalantari S, Delshad M (2013). Responses of different maturity stages of tomato fruit to different storage conditions. Acta Horticulture 1012:857-864.

Hong JH, Lee SK (1999). Comparison of ripening characteristics of vine- and room-ripened tomato fruit. Journal of the Korean Society of Horticultural Science 40(5):529-532.

Ilahy R, Hdider Ch, Lenucci MS, Tlili I, Dalessandro G (2011). Antioxidant activity and bioactive compound changes during fruit ripening of high lycopene tomato cultivars. Journal of Food Composition and Analysis 24:588-595.

Javanmardi J, Kubota Ch (2006). Variation of lycopene, antioxidant activity, total soluble solids and weight loss of tomato during postharvest storage. Postharvest Biology and Technology 41:151-155.

JędrszczykE, Skowera B, Kędzior R, Gawęda M (2017). The influence of ethephon application to processing tomato plants on yield structure in relation to weather conditions during the growing period. Folia Horticulturae 29(1): 75-81.

Karapanos IC, Chandra M, Akoumianakis KA, Passam HC, Alexopoulos AA (2015). The ripening and quality characteristics of cherry tomato fruit in relation to the time of harvest. Acta Horticulturae 1079:495-500.

Moneruzzaman KM, Hossain ABMS, Sani W, Saifuddin M (2008). Effect of stages of maturity and ripening conditions on the biochemical characteristics of tomato. American Journal of Biochemistry and Biotechnology 4(4):336-344.

Moneruzzman KM, Hossain ABMS, Sani W, Saifuddin M, Lenazi M (2009). Effect of harvesting and storage conditions on the postharvest quality of tomato (Lycopersicon esculentum Mill.) cv. Roma VF. Australian Journal of. Crop Science 3(2):113-121.

Oms-Oliu G, Hertog MLATM, Van de Poel B, Geeraerd AH, Nicolai BM, Ampofo-Asiama J (2011). Metabolic characterization of tomato fruit during preharvest development, ripening and postharvest shelf-life. Postharvest Biology and Technology 62:7-16.

Parker R, Maalekuu BK (2013). The effect of harvesting stage on fruit quality and shelf-life of four tomato cultivars (Lycopersicon esculentum Mill.). Agriculture and Biology Journal of North America 4(3):252-259.

Pijanowski E, Dłużewski M, Dłużewska A, Jarczyk A (2004). Ogólna Technologia Żywności [Food technology]. WNT Warszawa, Poland.

PN-71/A-75101. Przetwory owocowe i warzywne. Przygotowanie próbek i metody badań fizyko-chemicznych. Oznaczanie zawartości witaminy C [Fruits and vegetables processing. Sample preparation and methods of physico-chemical properties. Determination of vitamin C].

PN-90/A-75101.02 Przetwory owocowe i warzywne. Przygotowanie próbek i metody badań fizykochemicznych. Oznaczanie zawartości ekstraktu ogólnego [Fruits and vegetables processing. Sample preparation and methods of physico-chemical properties. Determination of total extract].

Saltveit ME (2005). Fruit ripening and fruit quality. Tomatoes. CABI Publishing, Netherlands pp 145-159.

Ozgen S, Sekerci S, Korkut R, Karabivik T (2012). The tomato debate: Postharvest ripened or vine ripe has more antioxidant? Horticulture, Environment, and Biotechnology 53(4):271-276.

Takahashi N, Maki H, Takayama K, Nishina H (2014). Estimation of tomato fruit color change with different maturity stages. Acta Horticulture 1037:385-390.

Tigist M, Workneh TS, Woldetsadik K (2013). Effects of variety on the quality of tomato stored under ambient conditions. Journal of Food Science Technology 50(3):447-486.

Toor RK, Savage GP (2006). Changes in major antioxidant components of tomatoes during postharvest storage. Food Chemistry 99:724-727.

Yemm EW, Wills AJ (1954). The estimation of carbohydrates in plant extracts by anthrone. Biochemistry Journal 54:508-514.

Weingerl V, Unuk T (2015). Chemical and fruit skin color markers for simple quality control of tomato fruits. Croatian Journal of Food Science and Technology 7(2):76-85. 
OPEN ACCESS

(c) (i)

The journal offers free, immediate, and unrestricted access to peer-reviewed research and scholarly work. Users are allowed to read, download, copy, distribute, print, search, or link to the full texts of the articles, or use them for any other lawful purpose, without asking prior permission from the publisher or the author.

License - Articles published in Notulae Botanicae Horti Agrobotanici Cluj-Napoca are Open-Access, distributed under the terms and conditions of the Creative Commons Attribution (CC BY 4.0) License. (c) Articles by the authors; UASVM, Cluj-Napoca, Romania. The journal allows the author(s) to hold the copyright/to retain publishing rights without restriction. 